
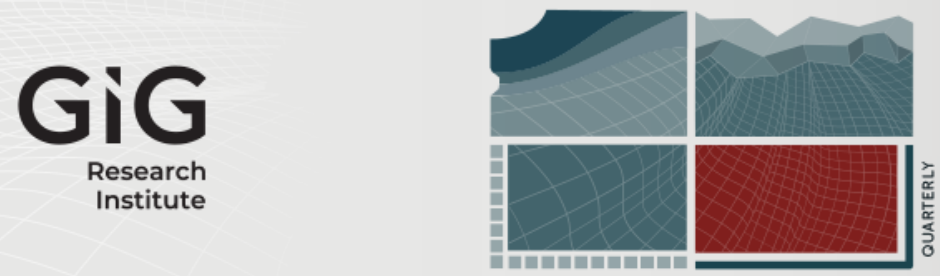

JOURNAL

OF

SUSTAINABLE

MINING

Volume 20 | Issue 1

Article 5

2021

\title{
The impact of precipitation on the groundwater of coal waste dump
}

Author(s) ORCID Identifier:

Tomasz Suponik (D) 0000-0002-4251-4275

Dawid Franke (iD 0000-0002-5522-6889

Robert Frączek (D) 0000-0001-6810-5915

Katarzyna Nowińska (iD) 0000-0002-4729-8719

Piotr Pierzyna (iD 0000-0003-4684-210X

Zenon Różański (iD) 0000-0002-0483-7276

Paweł Wrona (iD) 0000-0001-5978-4039

Follow this and additional works at: https://jsm.gig.eu/journal-of-sustainable-mining

Part of the Environmental Engineering Commons, Hydraulic Engineering Commons, and the Mining Engineering Commons

\section{Recommended Citation}

Suponik, Tomasz; Franke, Dawid; Frączek, Robert; Nowińska, Katarzyna; Pierzyna, Piotr; Różański, Zenon; and Wrona, Paweł (2021) "The impact of precipitation on the groundwater of coal waste dump," Journal of Sustainable Mining: Vol. 20 : Iss. 1 , Article 5.

Available at: https://doi.org/10.46873/2300-3960.1031

This Research Article is brought to you for free and open access by Journal of Sustainable Mining. It has been accepted for inclusion in Journal of Sustainable Mining by an authorized editor of Journal of Sustainable Mining. 


\title{
The impact of precipitation on the groundwater of coal waste dump
}

\begin{abstract}
The aim of the study was to assess the effect of climate change, mainly higher and lower precipitation, on the intensity of the impact of a coal waste dump on groundwater. The analysis used meteorological data for the Katowice region in 2002-2020 as well as data on the height of the groundwater table in the vicinity of the coal waste dump, and data on physicochemical parameters and chemical composition of groundwater in 2004-2020. Based on the analyses, it was found that the periods of drought in the Silesian Voivodeship, located in the south of Poland, occurred mainly in spring, while periods of excessive shortterm rainfall in summer. The period of excessive annual precipitation occurred between 2007 and 2010, followed by a long period of dry or very dry years that lasted until 2016. During the period of excess annual precipitation, the leachate from the waste dump caused a decrease in groundwater $\mathrm{pH}$ to 2.50 , while an increase in electrolytic conductivity (EC) and the concentration of sulphates and zinc to $5100 \mu \mathrm{S} /$ $\mathrm{cm}, 3890 \mathrm{mg} / \mathrm{L}, 18.5 \mathrm{mg} / \mathrm{L}$, respectively.
\end{abstract}

\section{Keywords}

climate change, precipitation, groundwater, coal waste dump, contaminants

Creative Commons License

\section{(c) (i)}

This work is licensed under a Creative Commons Attribution 4.0 License.

\section{Authors}

Tomasz Suponik, Dawid Franke, Robert Frączek, Katarzyna Nowińska, Piotr Pierzyna, Zenon Różański, and Paweł Wrona 


\title{
The impact of precipitation on the groundwater of coal waste dump
}

\author{
Tomasz Suponik ${ }^{a, *}$, Dawid Franke a , Robert Frączek ${ }^{b}$, Katarzyna Nowińska a , \\ Piotr Pierzyna ${ }^{a}$, Zenon Różański ${ }^{a}$, Paweł Wrona ${ }^{a}$ \\ a Silesian University of Technology, Faculty of Mining, Safety Engineering and Industrial Automation, Poland \\ b Tauron Wydobycie SA, Geology and Mine Surveying Department, Poland
}

\begin{abstract}
The aim of the study was to assess the effect of climate change, mainly higher and lower precipitation, on the intensity of the impact of a coal waste dump on groundwater. The analysis used meteorological data for the Katowice region in 2002-2020 as well as data on the height of the groundwater table in the vicinity of the coal waste dump, and data on physicochemical parameters and chemical composition of groundwater in 2004-2020. Based on the analyses, it was found that the periods of drought in the Silesian Voivodeship, located in the south of Poland, occurred mainly in spring, while periods of excessive short-term rainfall in summer. The period of excessive annual precipitation occurred between 2007 and 2010, followed by a long period of dry or very dry years that lasted until 2016. During the period of excess annual precipitation, the leachate from the waste dump caused a decrease in the $\mathrm{pH}$ of groundwater from ca. 5 to 2.50 , while an increase in electrolytic conductivity (EC) and the concentration of sulphates and zinc from ca. $1300 \mu \mathrm{s} / \mathrm{cm}$, $100 \mathrm{mg} / \mathrm{L}, 5 \mathrm{mg} / \mathrm{L}$ to $5100 \mu \mathrm{s} / \mathrm{cm}, 3890 \mathrm{mg} / \mathrm{L}, 18.5 \mathrm{mg} / \mathrm{L}$, respectively.
\end{abstract}

Keywords: climate change, precipitation, groundwater, coal waste dump, contaminants

\section{Introduction}

$\mathrm{T}$ he amount and intensity of precipitation caused by climate change have a significant impact on the environment [1-3]. The global rise in temperature may cause the contrast in precipitation between wet and dry regions, as well as between rainy and dry seasons, to increase over the decades [4]. Moreover, depending on the location, periods of extreme drought may be intertwined with more frequent heavy rainfall, increasing the risk of flooding [5,6]. Poland is one of the fastest-warming countries. Over several decades, conditions can occur with a large drop in precipitation and the absence of the typical cold and snowy winters.

The chemical composition of the precipitation water drained from industrial and urban areas as well as their physical and chemical properties depend on: a) the method of land development and use, b) type of waste deposited in the landfill, c) the intensity and duration of precipitation and the time between successive precipitation, d) the type of the materials used for the construction of roofs and other structures exposed to atmospheric precipitation, e) the type of drained surface and the method of snow removal, $f$ ) the type of liquid and solid substances used in the industrial plant, g) the emission of gases and dust to the atmosphere [7].

The link between climate change and human activities is well established [4,8]. In accordance with Bondu at al [2]. the quality of groundwater is strongly influenced by climatic changes, in particular the amount of precipitation and the temperature value. These impacts are related to changes in recharge, water table elevation, as well as flow processes and land use $[6,9,10]$. All this is associated with changes in the hydrological cycle.

An article by Ammar et al. [11] provides an overview of the available literature on methods for

Received 9 November 2020; revised 14 January 2021; accepted 24 January 2021.

Available online 6 March 2021

* Corresponding author.

E-mail address: tomasz.suponik@polsl.pl (T. Suponik). 
assessing groundwater vulnerability to climate change. Ouhamdouch et al. presented in their paper [12] the impact of climate change on the amount of precipitation and temperature, which in turn significantly affected the quality and quantity of groundwater in the Essaoura basin in Marocco. The same authors performed a hydrogeochemical analysis for this region [13]. They showed the evolution of the facies from $\mathrm{Cl}-\mathrm{Na}$ to $\mathrm{Cl}-\mathrm{Ca}-\mathrm{Mg}$ and other geochemical aspects and indicated that the climate change has an impact on the aquatic environment.

Climate change can also affect the aquatic environment near industrial waste dumps. The aim of the study was to assess the effect of climate change (mainly higher and lower precipitation) on the intensity of the impact of coal waste dump on groundwater. In particular, the impact of the amount of precipitation in the period from January 2004 to June 2020 on the chemical composition of water and the physical condition of the aquatic environment, i.e. the level of the groundwater table, was analysed.

\section{Methods}

The coal waste dump in Libiąz was selected for the analysis. It is located in the south of Poland, in the Lesser Poland Voivodeship. Coarse and finegrained waste stored there came from the coal mining and processing of Janina mining plant. Finegrained waste was stored in the northern part of the dump, in a settling pond, while in the southern and south-western part, coarse-grained waste. Drainage from the storage place is collected in its southern part and drained south towards the Vistula, $1.9 \mathrm{~km}$ away (Fig. 1).

The dump is located successively on the Quaternary, Tertiary, Carboniferous and Triassic formations. The aquifer under the dump consists of medium and fine sands. The thickness of the aquifer ranges from 4 to $16 \mathrm{~m}$. The aquifer is fed by precipitation. The free groundwater table ranges from $1.5 \mathrm{~m}$ BGL (below ground level) in the northwest to $8.8 \mathrm{~m}$ in the south-eastern part. Groundwater flows south towards the Vistula.

The analysis of the impact of climate change on the intensity of the impact of a waste dump on the aquatic environment was based on:

- The height of the groundwater table in the vicinity of the dump (the measurements were made using a hydrogeological whistle),

- Physicochemical parameters and chemical composition of groundwater (the following methods were used: - potentiometric for $\mathrm{pH}$
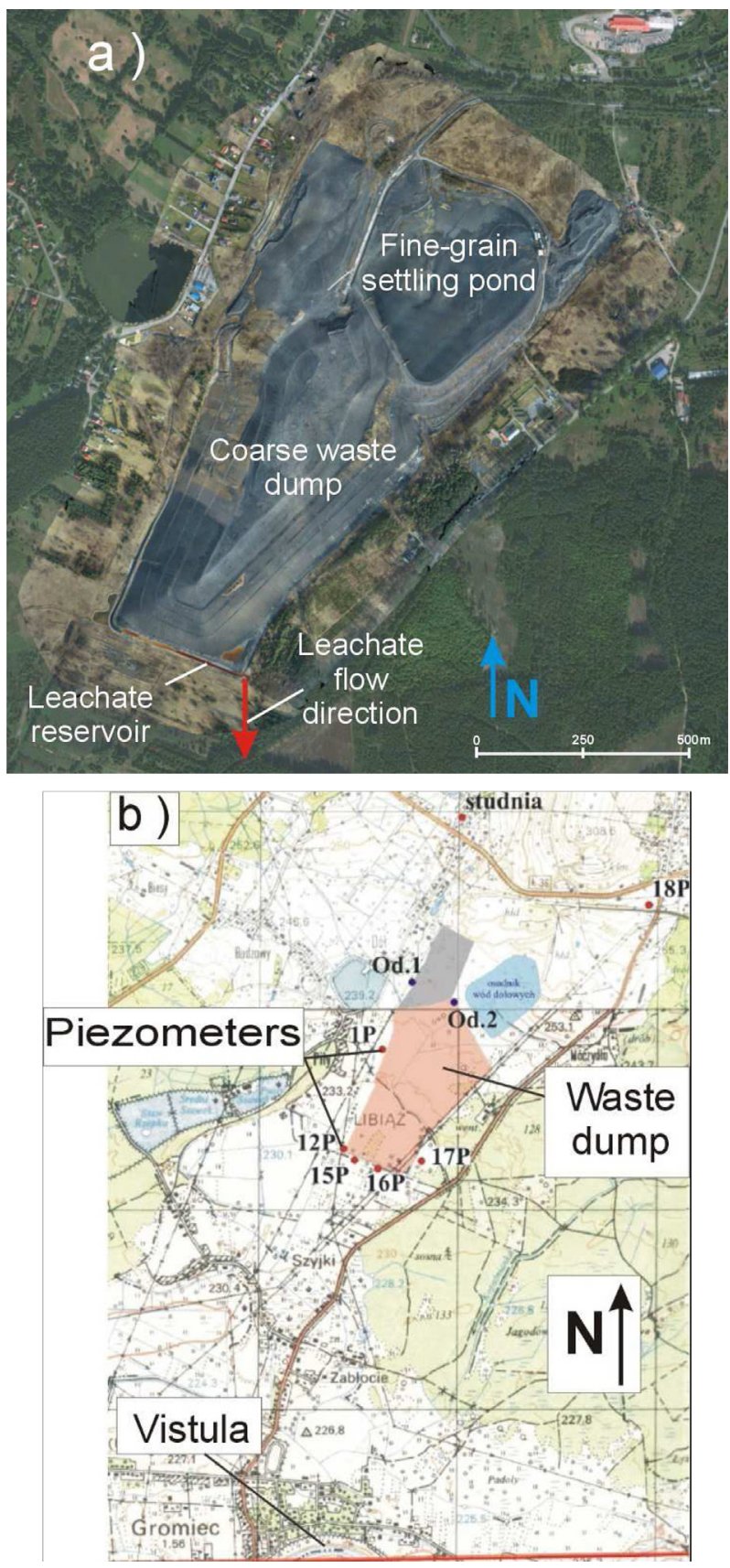

Fig. 1. a) the coal waste dump, Libiaz; b) the location of the Vistula and piezometers near the waste dump.

measurements (PN-90/C-04540/01); - conductometric for EC measurements (PN-EN 27888:1999); - spectrometric (ICP-AES) for measuring the concentrations of $\mathrm{Cu}, \mathrm{Ni}, \mathrm{Pb}, \mathrm{Cd}$, $\mathrm{Fe}, \mathrm{Zn}$, - spectrophotometric (UV-VIS) for measuring $\mathrm{SO}_{4}^{2-}, \mathrm{Cl}^{-}, \mathrm{Cr}(\mathrm{VI})$ concentrations.),

- Meteorological data for the area of Katowice from 2002 to 2020 . Katowice is located approximately $20 \mathrm{~km}$ from the assessed dump. 


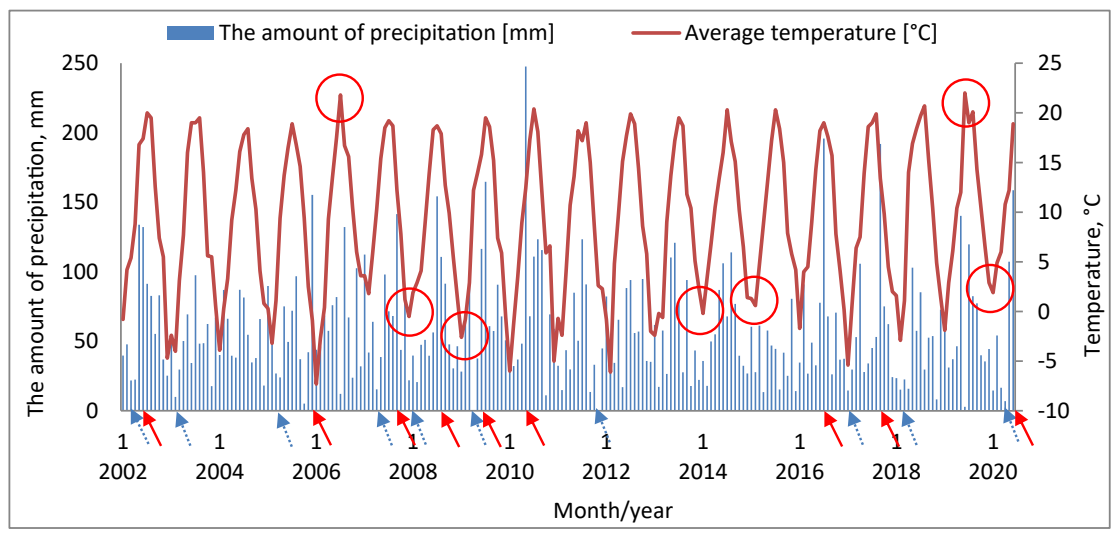

Fig. 2. Average monthly amount of precipitation vs. average monthly air temperature in the period from January 1, 2002 to June 30, 2020 (red circle on the graph - periods with temperatures above or below the average; blue dotted arrows indicate periods of excessive drought; red solid arrows indicate periods of excessive amounts of precipitation).

Water sampling was carried out in accordance with the recommendations of PN-ISO 5667-11: 2017 Water quality. Groundwater sampling guidelines. The chemicals and parameters were selected for analysis because they determine the state of wastewater discharged into the environment in accordance with the Polish regulatory criteria [Journal of Laws 2019 item 1311].

Groundwater water table as well as the physicochemical parameters and concentrations of selected chemicals in groundwater were determined for samples taken from six piezometers: $1-\mathrm{P}, 12-\mathrm{P}, 15-\mathrm{P}$, 16-P, 17-P, 18-P and from one well. All tests were carried out by Accredited Laboratories. Measurements were carried out 4 times a year (quarterly) for 16 years, i.e. from January 2004 to June 2020. The location of piezometers in the vicinity of waste dump is shown in Fig. 1b. The measurement points are located in two areas: in the area of waters flowing in from the north (piezometer 18-P and the well) and in the area of water outflow to the south (piezometers 1-P, 12-P, 15-P, 16-P, 17-P) towards the Vistula River.

The monitoring data of weather conditions (temperature and amount of precipitation) were obtained from the Institute of Meteorology and Water Management of Poland. The scope of data (monthly frequency) covers the period from January 2002 to June 2020.

\section{Results and discussion}

The average annual temperature for Katowice region is $9.0^{\circ} \mathrm{C}$ [14]. The warmest month is July with an average temperature of $19.2{ }^{\circ} \mathrm{C}$, and the coldest is January with an average of $-1.5{ }^{\circ} \mathrm{C}$. The average temperature in February is $-0.1{ }^{\circ} \mathrm{C}$, in March $3.5^{\circ} \mathrm{C}$, in April $9.3{ }^{\circ} \mathrm{C}$, in May $14.1{ }^{\circ} \mathrm{C}$, in June $17.1^{\circ} \mathrm{C}$, in August $18.5^{\circ} \mathrm{C}$, In September $13.8^{\circ} \mathrm{C}$, in October $9.0^{\circ} \mathrm{C}$, in November $4.9^{\circ} \mathrm{C}$ and in December $0.1{ }^{\circ} \mathrm{C}$. The average annual precipitation in the Katowice region is $710 \mathrm{~mm}$. For this region, February is the month with the lowest average precipitation of $38.9 \mathrm{~mm}$, while July is the month with the highest average of $106 \mathrm{~mm}$. The average amount of precipitation in January is $51.6 \mathrm{~mm}$, in March $49.1 \mathrm{~mm}$, in April $41.8 \mathrm{~mm}$, in May $70.9 \mathrm{~mm}$, in June $73.4 \mathrm{~mm}$, in August $77.4 \mathrm{~mm}$, in September $67.1 \mathrm{~mm}$, in October $43,5 \mathrm{~mm}$, in November $50.2 \mathrm{~mm}$ and in December $40.6 \mathrm{~mm}$.

Fig. 2 shows the average monthly amount of precipitation for the Katowice region correlated with the average monthly air temperature in the years 2002-2020. There were 5 winter seasons $(2007,2008$, 2014, 2015, 2020) and 2 summer seasons (2006 and 2019) with temperatures above average.

The period of excessive drought was defined as a period of at least 2 months reduction in the amount of precipitation by at least $50 \%$ in relation to the average amount of precipitation in the same period for a given region. In the analysed 18 years, 10 such periods were identified (most often in spring) (blue dotted arrows in Fig. 2). They were: March, April 2002; February, March 2003; March, April 2005; April, May 2007; December 2007 and January and February 2008; April and May 2009; September-November 2011; January and February 2017; December 2017 to April 2018 and March, April 2020.

In contrast, excessive amounts of precipitation were defined as $50 \%$ of the monthly exceeding of the amount of precipitation in relation to the average amount of precipitation in the same period. 9 such periods (most often in summer) were identified (red 


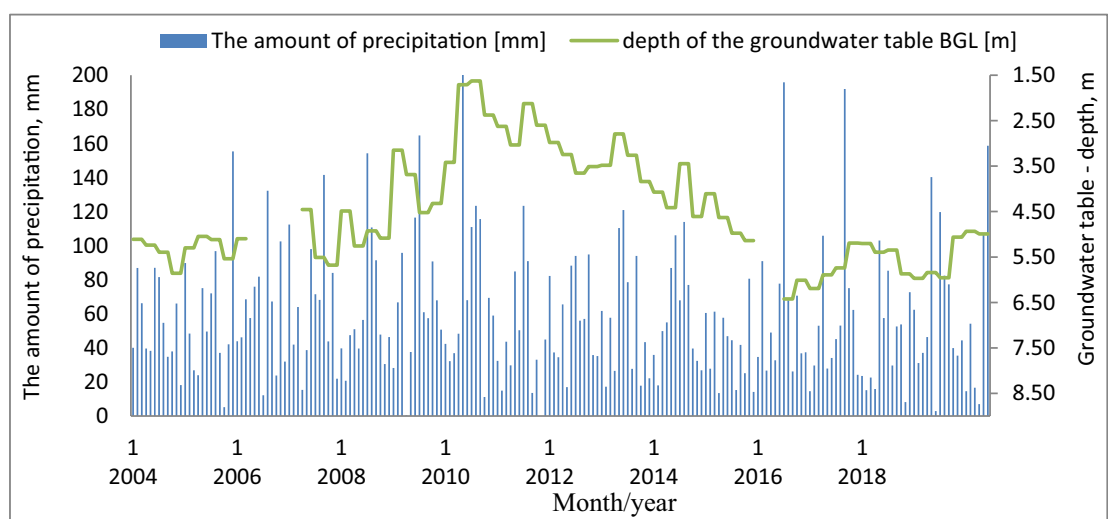

Fig. 3. The impact of precipitation on the average depth of the groundwater table.

solid arrows in Fig. 2). They were: May, June 2002; December 2005; September 2007; July to September 2008, June, July 2009; May and August, September 2010; July 2016; September 2017 and May, June 2020.

The years with the total amount of precipitation below $600 \mathrm{~mm}$ and above $800 \mathrm{~mm}$ were respectively: $2003(584 \mathrm{~mm}), 2011(562 \mathrm{~mm}), 2015(489 \mathrm{~mm}), 2018$ $(540 \mathrm{~mm})$ and $2007(801 \mathrm{~mm}), 2009(838 \mathrm{~mm})$ and 2010 (965 mm).

A long period of relatively low precipitation in $2003(584 \mathrm{~mm})$ caused that the groundwater level under the waste dump, in the first observed years (from January 2004 to March 2006), was low, ranging from 5.05 to $5.85 \mathrm{~m}$ BGL (below ground level) (Fig. 3). The large increase in the groundwater table from January 2009 to September 2010 was caused then by large amounts of precipitation in 2007 and 2009-2010. The water table increased at that time from 5.09 m BGL (December 2008) to $1.63 \mathrm{~m}$ BGL (September 2010). From January 2011 to September 2016, the groundwater level successively decreased to the level of $6.42 \mathrm{~m}$ BGL. The years in this period were either dry $(2012,2013)$ or very dry $(2011,2015)$. During this period, after several months of more intense precipitation, three six-month significant increases in the level of groundwater were recorded. They were: summer 2011 and 2014 and spring 2013.

From August 2016 to June 2020, the groundwater table increased from $6.42 \mathrm{~m}$ to $4.94 \mathrm{~m}$ BGL. In this period, the years 2016, 2017 and 2019 were characterized by slightly higher average annual amounts of precipitation.

The impact of precipitation on the $\mathrm{pH}$ value (Fig. 4) and electrolytic conductivity (EC) (Fig. 5) was analyzed on the basis of the results obtained from the piezometer 17. It is located south of the waste dump, i.e. where the leachate infiltrated into groundwater. This directly indicates the impact of a waste dump on groundwater.

The large impact of the amount of precipitation on the intensity of the waste dump's impact on groundwater is visible from July 2007, when the $\mathrm{pH}$

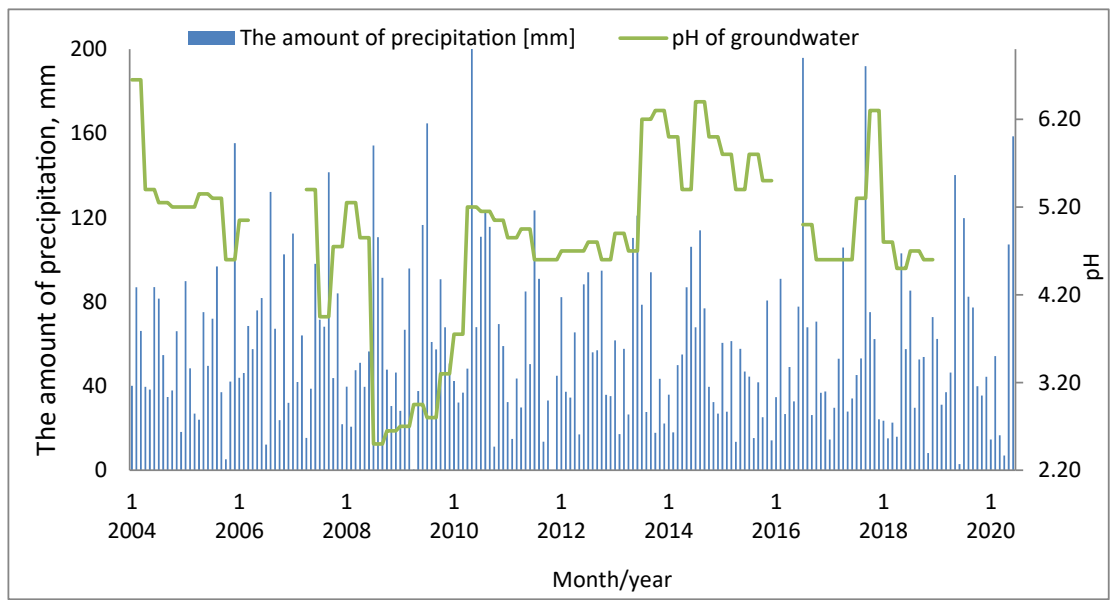

Fig. 4. The impact of precipitation on the $p H$ of groundwater taken from piezometer No. 17 . 


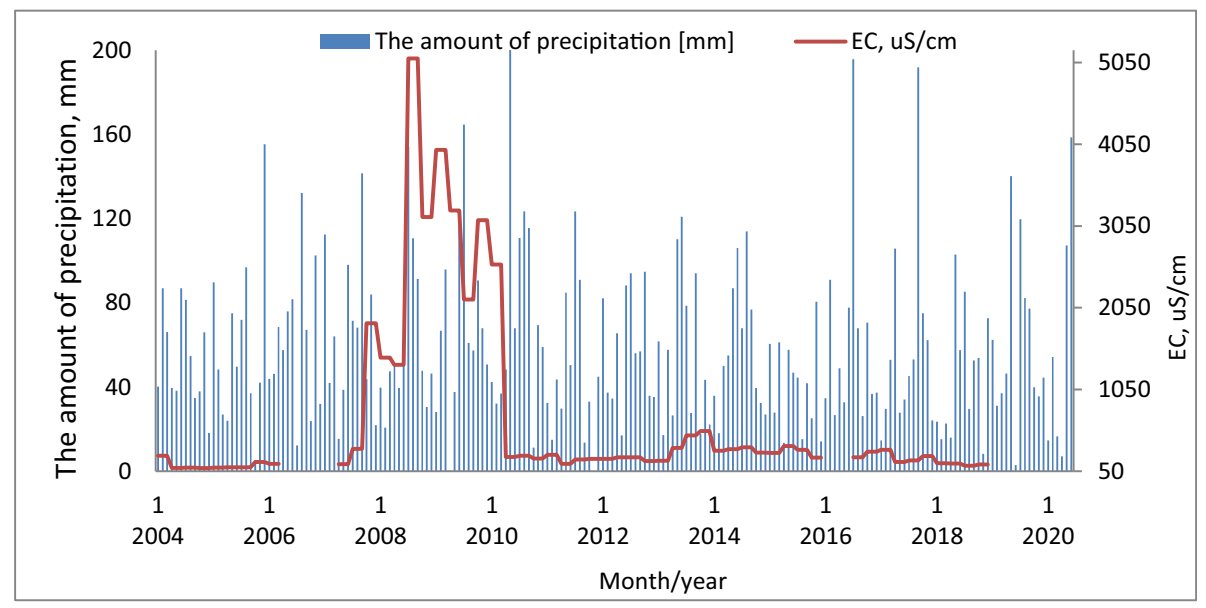

Fig. 5. The impact of precipitation on the EC of groundwater taken from piezometer No. 17.

dropped from 5.40 to 3.95 and the EC increased from 136 to $324 \mu \mathrm{s} / \mathrm{cm}$. In the following months, until April 2010, these influences were increasing and in the extreme period (summer 2008) they amounted to $\mathrm{pH}=2.50$, and $\mathrm{EC}=5100 \mu \mathrm{s} / \mathrm{cm}$. This corresponded to the highest level of groundwater. It can be said that a large amount of precipitation caused a large amount of leachate to flow into the groundwater, which resulted in an increase in the groundwater table during this period (Fig. 3). The leachate was characterized by a low $\mathrm{pH}$ value and a high content of dissolved substances, mainly sulphates and ions of the following heavy metals: $\mathrm{Zn}$, $\mathrm{Ni}, \mathrm{Fe}, \mathrm{Cu}$. This condition resulted in high EC values and very low groundwater $\mathrm{pH}$ values.

From April 2010 to September 2016, there was a gradual increase in $\mathrm{pH}$ and a drastic decrease in EC, which indicated a much smaller impact of the dump on groundwater. The $\mathrm{pH}$ value increased from 5.20 in April 2010 to a maximum of 6.40 in September 2014, while the EC varied from $226 \mu \mathrm{S} / \mathrm{cm}$ in April
2010 to $540 \mu \mathrm{S} / \mathrm{cm}$ in October 2013. This was related to the lowering of the groundwater table, which was caused by a much smaller inflow of leachate from the dump. As mentioned, from 2011 to September 2016 , there were dry $(2012,2013)$ or very dry $(2011$, 2015) seasons. Short-term intensive precipitation did not affect the $\mathrm{pH}$ and EC values of groundwater.

From August 2016 to June 2020, when the groundwater table increased from 6.42 to $4.94 \mathrm{~m}$ BGL, the $\mathrm{pH}$ dropped to 4.5. These conditions did not affect the EC.

Leakage from the waste dump that infiltrated into the groundwater between July 2007 to April 2010, resulted in the water containing mainly:

- sulphates - increased concentrations occurred in the 4th quarter of 2007, as well as in the period between the 3rd quarter of 2008 and the 1st quarter of 2010, and in these periods amounted to the maximum of $786 \mathrm{mg} / \mathrm{L}$ and $3890 \mathrm{mg} / \mathrm{L}$, respectively (Fig. 7),

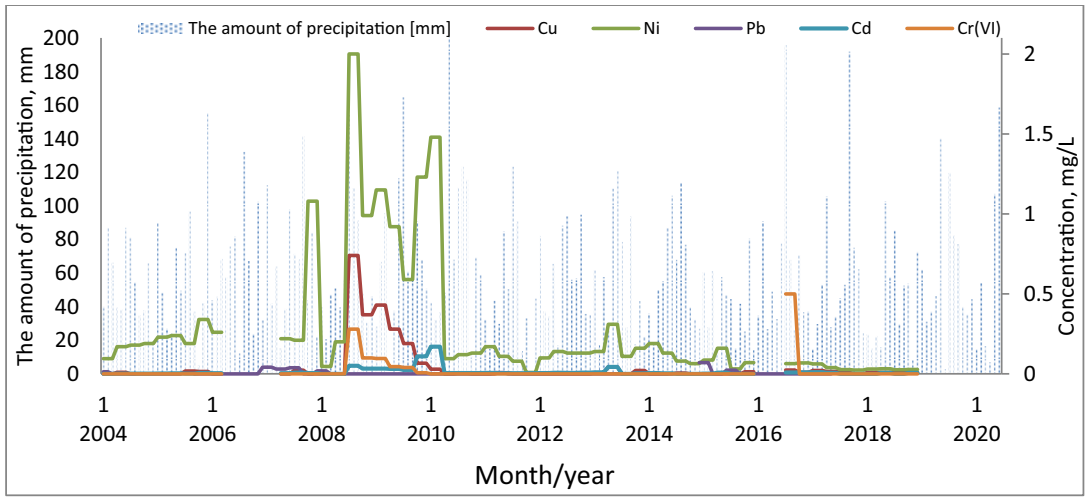

Fig. 6. Concentrations of $\mathrm{Cu}(\mathrm{II}), \mathrm{Ni}(\mathrm{II}), \mathrm{Pb}(\mathrm{II}), \mathrm{Cd}(\mathrm{II})$ and $\mathrm{Cr}(\mathrm{VI})$ in groundwater collected from piezometer No. 17. 


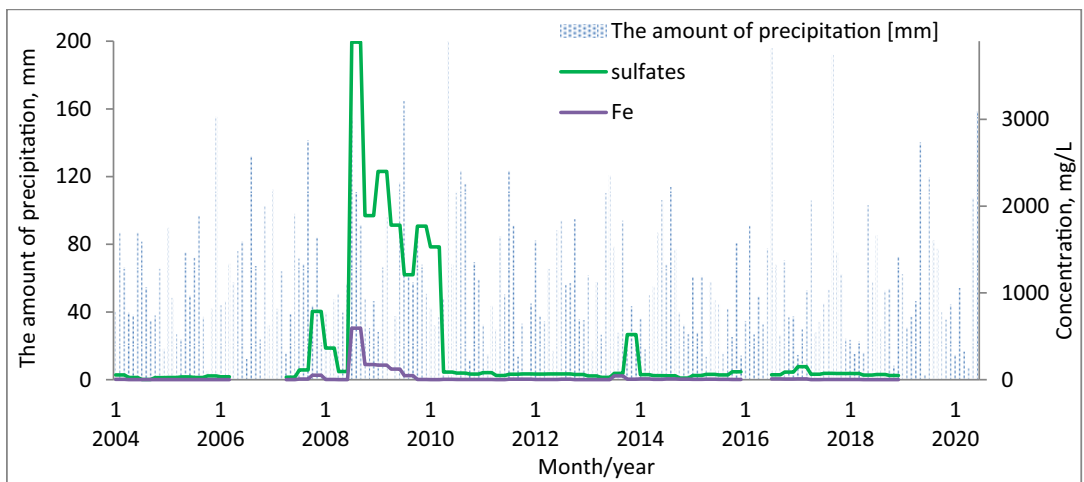

Fig. 7. Concentrations of sulphates and sums of $\mathrm{Fe}(I I I)$ and $\mathrm{Fe}(\mathrm{II})$ in groundwater taken from piezometer No. 17.

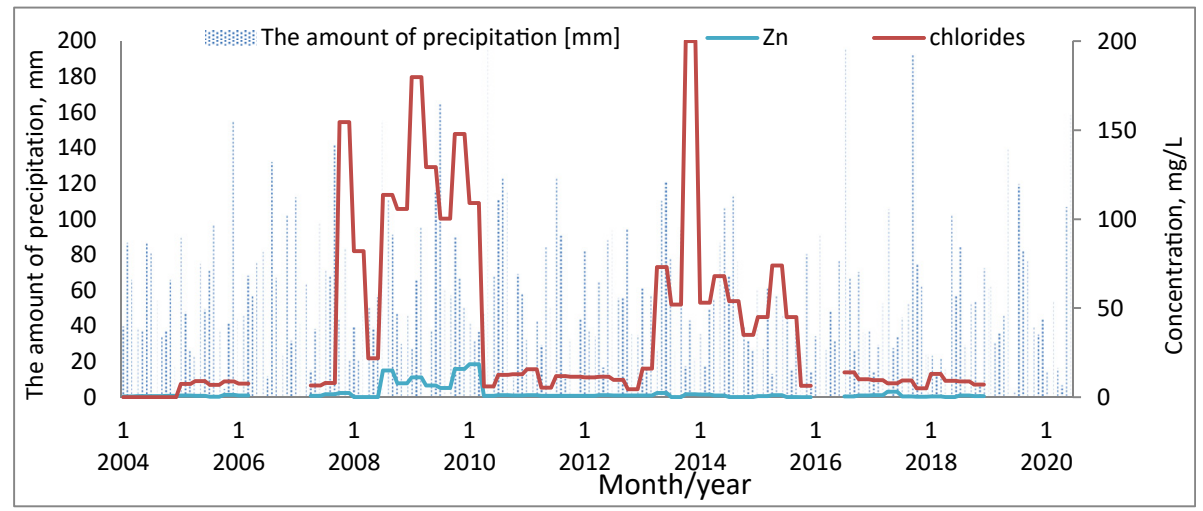

Fig. 8. Concentrations of Zn(II) and chlorides in groundwater taken from piezometer No. 17.

- chlorides - increased concentrations occurred in the 4th quarter of 2007 and in the period between the 3rd quarter of 2008 and the 1st quarter of 2010, and in these periods were maximum $154.5 \mathrm{mg} / \mathrm{L}$ and $179.8 \mathrm{mg} / \mathrm{L}$, respectively (Fig. 8),

- Zn - increased concentrations occurred in the 4th quarter of 2007 and in the period between the 3rd quarter of 2008 and the 1st quarter of 2010, and in these periods were maximum $2.4 \mathrm{mg} / \mathrm{L}$ and $18.5 \mathrm{mg} / \mathrm{L}$, respectively (Fig. 8),

- Fe - increased concentrations occurred in the 4th quarter of 2007 and in the period between the 3rd quarter of 2008 and the 3rd quarter of 2009, and in these periods amounted to a maximum of $51.0 \mathrm{mg} / \mathrm{L}$ and $593.5 \mathrm{mg} / \mathrm{L}$, respectively (Fig. 7),

- Ni - increased concentrations occurred in the 4th quarter of 2007 and in the period between the 3rd quarter of 2008 and the 1st quarter of 2010, and in these periods amounted to a maximum of $1.08 \mathrm{mg} / \mathrm{L}$ and $2.00 \mathrm{mg} / \mathrm{L}$, respectively (Fig. 6),

- $\mathrm{Cu}$ - increased concentrations occurred in the period between the 3rd quarter of 2008 and the 3rd quarter of 2009 and amounted to a maximum of $0.74 \mathrm{mg} / \mathrm{L}$ (Fig. 6),

- and in much lower concentrations of $\mathrm{Cr}$ (VI) and Cd (Fig. 6).

In the case of chlorides and $\mathrm{Ni}$, increased values also occurred in the period from the 2nd quarter of 2013 to the 3rd quarter of 2015 (Fig. 8) and, from 2004 to the 2nd quarter of 2015 (Fig. 6), respectively. On this basis, it can be assumed that nickel mainly corresponded to chlorides.

\section{Conclusions}

Based on the average amount of precipitation for the region of Katowice located in the south of Poland, it was found that the periods of drought in the Silesian Voivodeship occurred mainly in spring, while periods of excessive short-term precipitation in summer. The region experienced a period of excessive annual precipitation in 2007-2010, followed by a long period of dry or very dry years that lasted until 2016.

Many years of excessive precipitation affected groundwater contamination with leachate from the 
waste dump as well as the height of the groundwater table. During these periods, leachate from waste dump caused large changes in groundwater. The groundwater table had risen considerably and there were plenty of dissolved chemicals in it. Shortterm intense precipitation and drought had little effect on the height of the groundwater table and the level of groundwater pollution.

Therefore, in the event of excessive long-term precipitation, works related to the treatment of groundwater (remediation works) should be carried out in order to protect the aquatic environment against pollution from waste dumps. In the case of short-term (monthly) sudden precipitation or shortterm droughts, such work is not necessary.

\section{Ethical statement}

The authors state that the research was conducted according to ethical standards.

\section{Funding body}

This study was performed within the TEXMIN Project (The Impact of EXtreme weather events on MINing operations), funded by the Research Fund for Coal and Steel (RFCS) of the European Union, under Grant Agreement No 847250, and by the Polish Ministry of Science and Higher Education "PMW", under Grant Agreement No 5009/FBWiS/ 2019/2.

\section{Conflicts of interest}

None declared.

\section{References}

[1] Anawar HM. Impact of climate change on acid mine drainage generation and contaminant transport in water ecosystems of semi-arid and arid mining areas. Phys Chem Earth, Parts A/B/C 2013;58:13-21.

[2] Bondu R, Cloutier V, Rosa E, Benzaazoua M. A review and evaluation of the impacts of climate change on geogenic arsenic in groundwater from fractured bedrock aquifers. Water, Air, Soil Pollut 2016;227(9):296.

[3] Pearce TD, Ford JD, Prno J, Duerden F, Pittman J, Beaumier M, et al. Climate change and mining in Canada. Mitig Adapt Strategies Glob Change 2011;16(3):347-68.

[4] Stocker TF, Qin D, Plattner G-K, Tignor MM, Allen SK, Boschung J, et al. Climate Change 2013: the physical science basis. contribution of working group I to the fifth assessment report of IPCC the intergovernmental panel on climate change. Cambridge University Press; 2014.

[5] Taylor RG, Scanlon B, Döll P, Rodel M, Van Beek R, Wada Y, et al. Ground water and climate change. Nat Clim Change 2013;3(4):322-9.

[6] Green TR, Taniguchi M, Kooi H, Gurdak JJ, Allen DM, Hiscock KM. Beneath the surface of global change: impacts of climate change on groundwater. J Hydrol 2011;405(3-4): 532-60.

[7] Suponik T, Różański Z, Popczyk M. Heavy metals and sulfate removal from water by means of $\mathrm{Al}$ powder-cement-based filtration. Environ Protect Eng 2019;45(3).

[8] Parry M, Parry ML, Canziani O, Palutikof J, Van der Linden $P$, Hanson C. Climate change 2007-impacts, adaptation and vulnerability: working group II contribution to the fourth assessment report of the IPCC, vol. 4. Cambridge University Press; 2007.

[9] Jyrkama MI, Sykes JF. The impact of climate change on spatially varying groundwater recharge in the grand river watershed (Ontario). J Hydrol 2007;338(3-4):237-50.

[10] Stuart M, Gooddy D, Bloomfield J, Williams A. A review of the impact of climate change on future nitrate concentrations in groundwater of the UK. Sci Total Environ 2011;409(15): 2859-73.

[11] Aslam RA, Shrestha S, Pandey VP. Groundwater vulnerability to climate change: a review of the assessment methodology. Sci Total Environ 2018;612:853-75.

[12] Ouhamdouch S, Bahir M, Ouazar D, Carreira PM, Zouari K. Evaluation of climate change impact on groundwater from semi-arid environment (Essaouira Basin, Morocco) using integrated approaches. Environ. Earth Sci. 2019;78(15):449.

[13] Bahir M, Ouhamdouch S, Ouazar D, El Moçayd N. Climate change effect on groundwater characteristics within semiarid zones from western Morocco. Groundwater Sustain Dev 2020;11:100380.

[14] Climatebase.ru. Retrieved from: http://climatebase.ru/ station/12560/from2000?lang=en. 